\title{
The Matrimonial Property Law in Vietnam 1858-1975 in the Mirror of the European Legal Development
}

The development of Vietnam's legal system has been heavily influenced by invasions from China (178 BC-939 AC), France (1858-1954) and the United States (1954-1975). These invading forces applied their own regulations and administrative models to establish neocolonialism. Aside from direct European influence on Vietnam's legislative system, Eastern European socialist ideology has also played an essential role in shaping Vietnamese laws. This paper aims to describe the significant formative influences that Europe had on the Vietnamese legal system between 1858 and 1975. Specifically, this study focusses on the development of matrimonial property law.

Keywords: European impact - matrimonial property law-Vietnam

\section{Introduction}

During French colonial rule (1858 to 1954), Vietnam was divided into three territories: Southern [Cochinchine], Northern [Tonkin] and Central Vietnam [Annam]. Each region was assigned a distinct political status and, by extension, its own civil code. These three codes, which were modelled heavily on the 1804 French Civil Code (also known as the Napoleonic Code), were introduced in the Southern, Northern and Central territories in 1883, 1931 and 1936 respectively. By the end of their rule, the French had influenced almost every aspect of the Vietnamese legal system. ${ }^{1}$ Besides, the contribution of European legislation to Vietnamese statute through the socialist ideology following the 1922s was that it emphasised equality in all fields between men and women. Typically, equality in matrimonial property law was also concerned and protected.

\footnotetext{
${ }^{1}$ NGUYEN, The development 66-74.
}

The primary purpose of this study is to determine the degree to which the Napoleonic Code affected Vietnam's matrimonial property law between 1858 and 1954. Marital property laws were included in the Vietnamese Civil Codes promulgated by the French. The similarities and differences between the French and Vietnamese Civil Codes will be compared in the analyses below. From 1945 onwards, Vietnamese marital property laws were also guided by the Eastern European revolutionary socialist movement. In particular, the Vietnamese state incorporated socialist views on gender equality into the 1959 Act on Marriage and Family.

\section{The influence of French law on the development of Vietnam- ese law between 1858-1945}

When the French launched their initial invasion in 1858, Vietnam was ruled by the Nguyen Dynasty. The invasion took place in a step by step manner, gradually taking over all of Vietnam's 
major provinces and cities. The French initiated their campaign by invading the Da Nang province in September of $1858,{ }^{2}$ and subsequently moving into several southern provinces. Finally, in April 1862, the Nguyen Dynasty ceded the invaded areas to the French under the Treaty of Saigon.

This handover led to the official formation of the French colony of Cochinchine, while the feudal government of the Nguyen Dynasty continued to rule the Northern and Central regions. ${ }^{3}$

To ensure unification in the South, Cochinchine's operative and administrative functions were assigned exclusively to French naval officers. Vietnamese citizens played only a modest role in this new management system, serving as maids and assistants. The French modelled their judicial powers in South Vietnam on French law and introduced the Southern Civil Code in 1883, a document written in its entirety in French.

By 1883, France continued its invasion into Northern and Central Vietnam. Due to the erosion of the Nguyen Dynasty, the French forced King Nguyen to hand over the Northern and Central territories for protection. ${ }^{4}$ This power transfer meant that the Northern and Central provinces were under simultaneous management of both the Nguyen Dynasty and the French. In the North, the Nguyen Dynasty effectively served as a puppet administration, while the French assumed primary control. In the Central region, the Nguyen dynasty settled in $\mathrm{Hue}^{5}$ to reign and maintained parallel control with the French.

From 1883 to 1936, Vietnam relied on three separate Civil Codes for each of the three territories.

\footnotetext{
${ }^{2} \mathrm{Da}$ Nang is the largest developing province in Central Vietnam today.

3 TAYLOR, A history 445.

${ }^{4}$ Ibid. 446.

${ }^{5}$ Hue is a city in Central Vietnam and used to be the feudal capital of Vietnam under the Nguyen Dynasty (1802-1945).
}

To understand why the French issued independent Civil Codes instead of implementing a single unified legal system, it is essential to consider the political context of the time. In 1883, the South was a French colony, and therefore subject entirely to French rule.

By contrast, the Northern and Central regions were still controlled to some degree by the Nguyen Dynasty. As the relative influence of the French differed between the Northern and Central territories, the French also introduced distinct civil codes for these regions.

Moreover, the French invasion policy was to divide and conquer; by separating Vietnam into three administrative provinces, the French sought to minimise Vietnamese unity and undermine independent revolts. ${ }^{6}$

It is evident that the French greatly influenced the Vietnamese legal system from 1858 to 1954. Vietnamese Civil Codes were modelled heavily on the 1804 French Civil Code and specified certain marital property laws. From 1945, the North of Vietnam regained independence under the leadership of the Communist Party. This region built a civil and family law system that differed significantly from codes drawn up during the French colonial period. In 1959, North Vietnam promulgated the Act on Marriage and Family. These new laws were entirely independent from the pre-existing Civil Code. Besides, socialist countries often called it the Act on Marriage and Family instead of "Family Law" as in French and German Civil Codes. ${ }^{7}$ Following the reunification of 1975, however, Vietnam enacted several Civil Codes (19958,

\footnotetext{
${ }^{6}$ NGUYEN, The impact 65-82.

${ }^{7}$ There are some similarities in codification among socialist states in comparison to Chinese and Vietnemese experiences. See FENG, Review 331-398.

${ }^{8}$ Civil Code Nr. 44/1995/QH09 was issued by the $9^{\text {th }}$ Vietnamese National Assembly on 28 October 1995.
} 
$2005^{9}$ and $2015^{10}$ ) that drew heavily on the Civil Codes of France, Germany, and Switzerland. For example, the first chapter of the Vietnamese Civil Code 2015 governs general provisions like the German Civil Code. Vietnam's Civil Code still contains rules on civil relations involving foreign elements which are similar to the French Civil Code. These prove that the European civil and family law has a profound influence on Vietnam not only in the past but also in the present time.

\section{The Gia Long Code of $\mathbf{1 8 1 2}$}

It is particularly interesting that the French placed the Northern and Central provinces under their protection but allowed the Nguyen Dynasty to remain involved in their administration. Moreover, despite the introduction of new Civil Codes to both the Northern and Central regions, the French retained specific legal codes issued by the Nguyen Dynasty to ensure stability and acceptance by the local population. Accurately, the Gia Long Code was maintained to resolve criminal and civil disputes in the North and Central regions. This code was first issued by the Nguyen Dynasty in $1812^{11}$ and officially published in $1815 . .^{12}$ It was comprised of 398 articles and, while generally known as a penal code,,$^{13}$ covered both criminal and civil laws (66 Articles).

\footnotetext{
${ }^{9}$ Civil Code Nr. 33/2005/QH11 was issued by the $11^{\text {th }}$ Vietnamese National Assembly on 14 June 2005.

${ }^{10}$ Civil Code No. $91 / 2015 / \mathrm{QH} 13$ was issued by the $13^{\text {th }}$ Vietnamese National Assembly on 24 November 2019 [https://huvienphapluat.vn/van-ban/quyen-dansu/Bo-luat-dan-su-2015-296215.aspx].

${ }^{11}$ Aleavy, Dien in China and Vietnam 403-415.

12 VU, Dân luật khái luận 236.

${ }^{13}$ The Gia Long Code was newly issued in a Decree on 3. 7. 1933 by the King Nguyen (Vietnam) and the Governor-General (France) and applied in the Central Region. The Code's new version had 429 articles. In the introductory clause, the Code was modified only a
}

\section{The Southern Civil Code of 1883}

In the treaties of 1862 and 1874, the Nguyen Dynasty ceded the Southern provinces and three major cities (Hai Phong, Da Nang and Hanoi) to the French. The French government issued a directive on 25 May 1881 which stipulated that French judges should arbitrate disputes in the South. As a result, the French rapidly initiated codification in the South. Initially, the newly introduced legal regulations were split into three volumes: the first volume regulated nationality, the second volume prescribed civil status, and the third volume addressed residential regulations. The first and third volumes referred to the first volume of the French Civil Code. ${ }^{14}$

The French President issued the second volume on 3 October 1883 . This volume, commonly referred to as the simplified Civil Code of the South, consisted of seven chapters, with chapters IV-X stipulating matrimonial and family law. These chapters took effect on 26 March 1884. Chapters IV-X regulated the issues of abandonment, marriage, divorce, parent-child relationship, adoption, personal rights, minors, and guardians.

By 1883, the Southern Civil Code (known as "Précis de la Législation Civile Anammite"15) applied to the Southern provinces and three major cities: ${ }^{16}$ Hanoi, Hai Phong, and Da Nang. ${ }^{17}$ This civil law was quite superficial and did not offer much guidance on marriage and inheritance regulations. Vietnamese and French mar-

few times to meet the demands of the Vietnamese society and traditional customs. See BÙI and BERT, Code Penal de L'annam 282.

${ }^{14}$ BÙI, BERT, Code Penal de L'annam 282.

${ }^{15}$ BRIESEN, The French "État legale" 75-77.

16 These three major cities, which are not in the South but were still under French control, held important sea trade positions.

${ }^{17}$ Hai Phong is a port city in the Northeast of Vietnam. 
riage and family laws were distinctly different at the time; unlike the French Civil Code, Vietnamese feudal laws emphasised the patriarchal value of a man and relied on customs to judge family disputes. This fundamental difference made it especially difficult to directly transfer French matrimonial property law into the Southern Civil Code of 1883. French judges dealing with marital property disputes had to comply with the provisions of the Gia Long Code and traditional Vietnamese customs. Besides, if the above-mentioned two acts did not anticipate all marital property disputes in South Vietnam, the judge should apply case law to settle the conflict. ${ }^{18}$ Case law in this context referred to domestic and French legal cases (mainly civil obligations) that were used as precedents in Vietnamese legal cases. While French judges initially relied on French case law ${ }^{19}$ to guide their judgements, the marked differences between Vietnamese and French regulations made this extremely difficult at times. Specifically, in Vietnamese cases involving matrimonial property law, it was effectively impossible to apply French family case precedents. Accordingly, from 1895 onwards, Southern Vietnamese case law was collected in monographs, such as the "Journal judiciaire de La Conchinchine et du Cambodge" ${ }^{20}$ This finally allowed French judges to apply Vietnamese case precedents to settle disputes in the South.

\footnotetext{
${ }^{18}$ VU, Pháp chế sử 27.

${ }^{19}$ The French case law was later translated into Vietnamese by two Vietnamese judges in a book called "Important Case Law". See TRAN, NGUYEN, Những án lệ quan trọng [Important case law] 20-54.

${ }^{20}$ The French Republic published the "Journal judiciaire de La Conchinchine et du Cambodge", which was the collections of civil and criminal case laws in Vietnam and Cambodia during the year 1895.
}

\section{The Northern Civil Code of 1931}

In 1931, the French enacted the Northern Civil Code and terminated the Northern validity of the Gia Long Code. This new civil law was issued bilingually, in both French (known as "Code Civil à'usage des jurisdictions indigènes $\mathrm{du}$ Tonkin") and Vietnamese. It had four volumes and 1455 articles. ${ }^{21}$

The Northern Civil Code was issued on 30 March 1931 and promulgated on 1 July 1931. The matrimonial and family law was regulated in the first volume (Article 68-461).22 Like the Southern Code, the Northern Code referred heavily to the French Civil Code. The concept of communal property was recognised in these regulations.

Matrimonial property law allowed spouses to choose between a marital property agreement or a statutory property system. Moreover, the wife was given the right to own property independently of her spouse (Article 113). Where the South relied mostly on customs and case law to resolve disputes, the Northern Civil Code did precisely the opposite; laws were interpreted literally, and judges applied written regulations to settle family conflicts. The Northern Code did not consider precedents to be a valid source of law.

According to Article 106 of the Northern Civil Code, if a married couple did not pre-establish a marital agreement, the statutory communal property law would be applied automatically. This law, like the communal property law, stipulated initially in Article 1041 of the 1804 French Civil Code, stated that all assets

\footnotetext{
${ }^{21}$ The Northern Civil Code was issued in a Decree dated 30.3. 1931 by the French Ambassador to the North and was effective from 1.7.1931. See NGUYEN, Đặc trưng cơ bản của Bộ dân luật bắc kỳ 6-38.

22 Phan, TRUONG, Các chế độ hôn nhân và gia đình Việt Nam xưa và nay 40 .
} 
(including donated/inherited real estate) became communal property following marriage. As such, spouses could retain separate property following prior agreement only.

\section{The Central Civil Code of 1936}

From 1936, France promulgated the Central Civil Code and abolished the validity of the Gia Long Code. It was issued bilingually in French (known as Code Civil à'usage des jurisdictions indigènes de L'Annam) and Vietnamese (known as Hoang Viet Trung Ky Law) which ensured application to both the French government and the Nguyen Dynasty. The Central Civil Code had five volumes ${ }^{23}$ and 1709 articles. ${ }^{24}$

Article 79 of the Central Civil Code addressed polygamy based on feudal regulations. The concubine should be allowed to reside with the extended marital family, including the main wife. The main wife had more power than the concubine in all respects. Accordingly, the concubine did not have separate property and obeyed to both the main wife and the husband. The husband retained his primary patriarchal rights (Article 114 of the Central Civil Code).

If the husband accepted that the concubine could stay separately and independently from the extended family, she could establish a separate property. "If the husband owed a debt, the second wife had no obligation to pay the debt on behalf of her husband. When the husband was deceased, she still retained her assets (Article 223 of the Central Civil Code). This part of

\footnotetext{
${ }^{23}$ The first volume was issued under Decree Nr. 51 on 13.7. 1936. The second volume was issued under Decree Nr. 95 on 8. 1.1938. The third, fourth and fifth volumes were issued under Decree Nr. 59 on 28. 9. 1939.

${ }^{24}$ BuI, BerT, Code Penal de L'annam 5; NGuYen, Vietnamese Law 337-339.
}

the property was not merged into the whole communal property managed by the main wife when the husband demised". ${ }^{25}$

It is important to note that spouses only formed communal property when they no longer resided in their parental homes. According to Article 206 of the Central Civil Code, the marital estate law was applicable only when the husband was considered the head of the family and had full authority to represent the family members he lived with. As patriarchal law applied to the head of the family, children and grandchildren that remained in their parental homes following marriage deferred their patriarchal rights to the head of the household.

Like the Northern Civil Code, the Central Civil Code recognised two types of matrimonial properties: a marital agreement property and communal property. The marriage agreement model allowed couples to decide on ownership, while the communal property system only recognised the existence of common property. For a property to be considered a 'marital agreement property', couples had to draw up a prior written agreement and have it legalised by an appropriate authority. This agreement could not be modified after the parties had ratified it, and only upon dissolution of the marriage would the agreement be terminated. A note of the agreement was made in the marriage certificate to inform and protect third persons in secured transactions with the spouses. ${ }^{26}$ This law had similarities with Articles 1393, 1394 and 1945 of the 1804 Napoleonic Code.

\footnotetext{
${ }^{25}$ VU, Dân luật lược khảo 603.

${ }^{26}$ PHAN, Phụ nữ Việt Nam trước pháp luật 58-59.
} 


\section{The influence of Eastern European socialism on women's rights in Vietnamese family law from 1945 onwards}

By 1954, France had withdrawn its troops from Vietnamese territories. From 1954 to 1975, the USA, a French ally, replaced France to rule Southern Vietnam under the Southern Republic system. Vietnam was divided into the North and the South, as the ascent of politician Ho Chi Minh led to Vietnamese independence in the North. From this point onwards, Northern Vietnam has remained under the leadership of the Communist Party and followed a socialist orientation. This Soviet movement originated in Eastern Europe in 1922, and gradually spread to China and Vietnam. Ho Chi Minh, a communist leader, called for the implementation of gender equality. He pointed out that "independence from colonial oppression and the beginning of communist governance would bring a new and better role for women in Vietnamese society". ${ }^{27}$ Hence, the Act on Marriage and Family was issued by the State in December 195928 and acknowledged women's possessive right. The law stipulated that spouses have the equal right to own, enjoy, and use common property. This law was founded on the idealistic views of Marx, Lenin, and Engels. The latter, in particular, had strong viewpoints on family law, private property and the State. ${ }^{29}$

\footnotetext{
${ }^{27}$ WALSH, The law of the family 69; POTHIER, Propagandist representation.

${ }^{28}$ Law Nr. 2/1959/QH dated on 29. 12. 1959. The National Assembly on Marriage and Family which was applied to the North of Vietnam

[https://huvienphapluat.vn/van-ban/quyen-dan-su/

Luat-Hon-nhan-va-gia-dinh-1959-2-SL-36857.aspx].

${ }^{29}$ It is not hard to figure out the similarities on principles which were stipulated in civil law and family law between Soviet countries at that time. See ENGELS, From the origin of the family $45-88$.
}

The 1959 Act stated that "in the family, husband and wife are equal in all aspects". Regarding property ownership, the Act on Marriage and Family stipulated that spouses owned common property and would have to forego all independent property rights (Article 15). This rule applied to properties acquired before marriage, as well as those acquired during the course of the marriage. In general, this would create imbalances when one party made less of an effort than the other to contribute to property purchases. Another striking feature of the 1959 Marriage and Family Act was that it encouraged progressive and monogamous families, supported gender equality, and valued the rights of both women and children (Article 1).

In April 1975, South Vietnam acquired independence, and the country was reunified to form the Socialist Republic of Vietnam. From 1975 to the present day, Vietnam has undergone three major regulatory changes insofar as matrimonial property law is concerned. These changes were introduced in the Marriage and Family Acts of 1986, ${ }^{30} 2000^{31}$ and 2014. ${ }^{32}$ The $2014^{33}$ Act stipulates that spouses have the right to choose a statutory property regime or a marital agreement regime (also known as a marriage contract) at the time of their marriage. "If married couples do not have an agreement on the

\footnotetext{
${ }^{30}$ Law Nr. 21-LCT/HDNN7 dated on 29. 12. 1986 by The National Assembly on Marriage and Family [https://huvienphapluat.vn/van-ban/quyen-dan-su/ Luat-Hon-nhan-va-gia-dinh-1986-21-LCT-HDNN737246.aspx].

${ }^{31}$ Law Nr. 22/2000/QH10 was issued by the National Assembly on Marriage and Family on 10. 6. 2000 [https://thuvienphapluat.vn/van-ban/quyen-dan-su/ Luat-Hon-nhan-va-Gia-dinh-2000-22-2000-QH1046450.aspx].

32 This law became effective on 1. 1. 2015 in Vietnam.

${ }^{33}$ Law Nr. 52/2014/QH13 was issued by the National Assembly on Marriage and Family on 19.6. 2014, gazette number 52/2014/QH13

[https://huvienphapluat.vn/van-ban/quyen-dan-su/ Luat-Hon-nhan-va-gia-dinh-2014-238640.aspx].
} 
marriage contract, the statutory property regime will automatically be applied." 34 This was the first time that the Act on Marriage and Family law recognised the marital agreement property regime since 1975. The concept of a communal property regime had been replaced as a statutory property regime since the 2014 Marriage and Family Act enacted. The Acts 1959, 1986 and 2000 did not have either the concept of communal property or the notion of statutory property regime within their regulation. Instead, these Acts just addressed marital properties, including common property and separate property.

\section{Conclusion}

In summary, Vietnam's matrimonial property law has been significantly influenced by the Napoleonic Code. Introduction of Frenchinspired civil codes led to sweeping changes in the Vietnamese feudal legal system. From $179 \mathrm{BC}$ to $939 \mathrm{AC}$ (the period of Chinese conquest), Vietnam had been greatly influenced by Chinese Confucianism. ${ }^{35}$ This school of thought maintained that the husband should be seen as head of the family, and owner of all family assets. The wife, by contrast, was seen as lesser than the husband, and left virtually unprotected. Accordingly, when the French first introduced the concept of communal property, this was seen as a very progressive change. Nevertheless, the French Civil Code still maintained that the husband was head of the family and had the right to manage all communal assets, including those belonging to his wife. When the Soviet movement of gender equality reached Vietnam,

\footnotetext{
${ }^{34}$ Art. 7 of Decree N.126/2014/ND-CP was issued on 31. 12. 2014 by the Vietnamese Government. This Decree is detailing several Articles and Measures for implementation of the Act or Marriage and Family 2014.

${ }^{35}$ TAI, The status of women in traditional Vietnam: A comparison of the code of the Le dynasty 97-145, 525 .
}

the 1959 Act on Marriage and was introduced to formally recognise the equal rights of husband and wife in matrimonial property law.

In conclusion, French colonialism and Eastern European socialism undeniably influenced Vietnamese civil and family law, particularly as it relates to marital property from 1858 to 1975 . Even in the present day, the European legal culture continues to affect Vietnamese codification due to its tremendous reputation in the legislative sphere.

\section{Correspondence:}

Linh Thị Mỹ NGuYỄN, Doctoral student

University of Pécs

Faculty of Law Hungary

48-as tér 1

$\mathrm{H}-7622$ Pécs

my.linh@ajk.pte.hu

ORCID-Nr. 0000-0001-6611-8982 


\section{Literature:}

H. Mc. Aleavy, Dien in China and Vietnam, in: The Journal of Asian Studies 17/3 (1958) 403-415.

D. BRIESEN, The French "État legale" in Vietnam. Between Legal Pluralism and Police State, in: Ulrich von Alemann (ed.), The State of law. Comparative perspective on the rule of law in Germany and Vietnam (Düsseldorf 2017).

T. H. BuI, Reu P. BERT, Code Penal de L'annam [Hoang Viet Law] (Vietnam 1933) 5.

ENGELD, From the origin of the family, private property and the state (Hottingen-Zurich 1884) 45-88.

$X$. FENG, Review of the development of marriage law in the people's republic of China, in: University of Detroit Mercy Law Review 3/79 (2002) 331-398.

D. N. NGUYEN, Vietnamese Law, in: The Quarterly Journal of the Library of Congress 23 (1966) 337339.

L. T. M. NGuYEN, The development of matrimonial property law in Vietnam, in: DÍKÉ 2/2 (2018) 6674.
IDEM, The impact of the French colonial law on the development of matrimonial property law in $\mathrm{Vi}$ etnam, in: DÍKÉ 3/1 (2019).

T. K. NGUYEN, Đặc trưng cơ bản của Bộ dân luật Bắc kỳ năm 1931 (LLM. Diss, Hanoi National University 2016) 6-38.

T. D. Phan, H. T. TRUONG, Các chế độ hôn nhân và gia đình Việt Nam xưa và nay (Saigon 2012).

T. V. PHAN, Phụ nữ Việt Nam trước pháp luật (Saigon 1955) 58-59.

T. V. TAI, The status of women in traditional Vietnam. A comparison of the code of the Le dynasty (14281788) with the Chinese codes, in: Journal of Asian History 15/2 (1981) 97-145.

K. W. TAYLOR, A history of the Vietnamese (Cambridge 2013).

L. T. TRAN, T. V. NGUYEN, Những án lệ quan trọng (Saigon 1962).

Th. J. WALSH, The law of the family in Vietnam (California Western 2011) 61-122.

M. V. VU, Dân luật khái luận (Saigon 1961).

IDEM, Dân luật lược khảo (Saigon 1962).

T. Q. VU, Pháp chế sử (Saigon 1968). 